\title{
Peran masa kerja pada hubungan antara kepuasan kerja dan intensi meninggalkan organisasi pada guru sekolah swasta
}

\author{
Yohanes Christian $^{(1)}$, Debora Eflina Purba ${ }^{(2)}$ \\ ${ }^{(1),(2)}$ Fakultas Psikologi, Universitas Indonesia, Depok, Indonesia
}

\begin{abstract}
Job satisfaction has been empirically known to be a strong predictor of turnover intentions. However, previous studies have also found that other variables moderated the relationship between job satisfaction and turnover intentions. Drawing on the side-bet theory, this research aimed to examine the role of the duration of employment at the current school in the relationship between job satisfaction and turnover intentions. Participants were 239 K12 teachers from private schools in Jakarta and its surroundings, who were recruited through convenient sampling. The design of this research was a correlational study and the findings revealed that first, job satisfaction was negatively related to turnover intentions, denoting that the higher the job satisfaction, the lower the turnover intentions. The second finding showed that the duration of employment played a significant moderator in the relationship between the two variables. In particular, the negative correlation between job satisfaction and turnover intentions was more pronounced among participants with a long duration of employment than participants with a short duration of employment. The results of this research imply that in line with the side-bet theory, individuals tend to be unwilling to sacrifice what they get from an organization they work for despite having low levels of job satisfaction.
\end{abstract}

Keywords: duration of employment, job satisfaction, $K 12$ teachers, private schools, turnover intentions

Kepuasan kerja secara empiris telah diketahui sebagai prediktor kuat dari intensi meninggalkan organisasi. Namun, penelitian terdahulu juga menemukan peran variabel lain sebagai moderator hubungan antara kepuasaan kerja dan intensi meninggalkan organisasi tersebut. Menggunakan teori side-bet, penelitian ini bertujuan untuk menguji peran lama kerja di sekolah saat ini dalam hubungan antara kepuasan kerja dan intensi meninggalkan organisasi. Jumlah partisipan adalah 239 guru tingkat TK, SD, SMP, dan SMA dari sekolah swasta di Jakarta dan sekitarnya, yang direkrut menggunakan teknik convenience sampling. Desain penelitian ini adalah kuantitatif korelasional. Hasil penelitian menunjukkan bahwa, pertama, kepuasan kerja berhubungan secara negatif dengan intensi meninggalkan organisasi dimana semakin tinggi kepuasan kerja maka semakin rendah intensi meninggal organisasi. Temuan kedua menunjukkan bahwa lama kerja berperan secara signifikan sebagai moderator dalam hubungan antar kedua variabel tersebut. Korelasi negatif antara kepuasan kerja dan intensi meninggalkan organisasi lebih kuat pada partisipan dengan tingkat lama kerja yang lebih tinggi dibandingkan dengan partisipan dengan tingkat lama kerja yang lebih rendah. Hasil penelitian ini mengimplikasikan bahwa, selaras dengan teori side-bet, individu cenderung tidak bersedia mengorbankan apa yang mereka dapatkan selama bekerja di organisasi meskipun tingkat kepuasan kerja yang dimilikinya cenderung rendah.

Kata kunci: guru di sekolah swasta, intensi meninggalkan organisasi, kepuasan kerja, masa kerja

MEDIAPSI, 2021, Vol. 7(2), 150-165, DOI: https://doi.org/10.21776/ub.mps.2021.007.02.7

Received: 22-05-2021. Revised: 26-06-2021. Accepted: 08-07-2021. Published online: 25-12-2021

Handling Editor: Ali Mashuri, Universitas Brawijaya, Malang, Indonesia.

*Corresponding author: Debora Eflina Purba, Fakultas Psikologi, Universitas Indonesia, Depok, Indonesia. E-mail: eflina@ui.ac.id

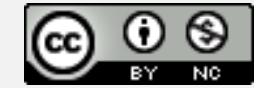

This work is licensed under a Creative Commons Attribution-NonCommercial 4.0 International License.

How to cite this article in accordance with the American Psychological Association (APA) $7^{\text {th }}$ guidelines:

Christian, Y., \& Purba, D. E. (2021). Peran masa kerja pada hubungan antara kepuasan kerja dan intensi meninggalkan organisasi pada guru sekolah swasta. MEDIAPSI, 7(2), 150-165. https://doi.org/10.21776/ub.mps.2021.007.02.7 


\section{Pendahuluan}

Penelitian terkait turnover (perilaku meninggalkan organisasi) pada guru di sekolah telah banyak dilakukan, karena perilaku ini dapat menimbulkan dampak negatif yang besar bagi organisasi (Loeb dkk., 2005). Penelitian ini berfokus pada intensi meninggalkan organisasi (turnover intentions), karena pada tahap ini individu masih belum keluar dari organisasi sehingga organisasi dapat mencari penyebab mengapa individu berpikir untuk keluar dari organisasi dan melakukan intervensi untuk menurunkan intensi keluar dari organisasi (Purba dkk., 2016). Penelitian sebelumnya menunjukkan telah banyak variabel prediktor dari intensi meninggalkan organisasi, seperti komitmen organisasi, persepsi terhadap alternatif pekerjaan yang tersedia (job alternative), stresor terkait peran di pekerjaan (role stressor), keterlibatan kerja, motivasi persepsi kinerja organisasi, kepuasan kerja, dan kepercayaan (trust) (Bonenberger dkk., 2014; Chao dkk., 2015; Huang dkk., 2017; Kartika \& Purba, 2018; Lee dkk., 2018; Rubel dkk., 2017; Swider dkk., 2011; Zeffane \& Bani Melhem, 2017).

Pada penelitian ini, peneliti memilih kepuasan kerja sebagai prediktor bagi intensi untuk meninggalkan organisasi, karena variabel ini telah secara luas diteliti sebagai prediktor dari intensi meninggalkan organisasi, tetapi belum banyak diteliti pada guru sekolah swasta. Secara sederhana, kepuasan kerja mengacu pada apakah individu merasa puas atau tidak pada aspek-aspek dalam pekerjaannya. Spector (1997) mendefinisikan kepuasan kerja sebagai suatu perasaan atau penilaian atas pekerjaan yang dimilikinya, baik secara keseluruhan, maupun secara aspek-aspek pada pekerjaannya.

Meskipun penelitian terdahulu secara konsisten menemukan kepuasan kerja sebagai prediktor yang signifikan dari intensi meninggalkan organisasi, koefisien korelasinya bervariasi cukup besar, yakni antara -.17 sampai dengan .66 (Bravo dkk., 2019; Chung dkk., 2017; De Simone dkk., 2018; Kafumbu, 2019; Mahdi dkk., 2016; Zeffane \& Melhem, 2017). Koefisien korelasi yang bervariasi tersebut di atas menunjukkan effect size kecil hingga besar, yang mengindikasikan adanya pengaruh variabel lain pada hubungan di antara kedua variabel. Selain itu, beberapa penelitian sebelumnya menunjukkan terdapat moderator pada hubungan antara kepuasan kerja dan intensi meninggalkan organisasi, seperti self-determined work motivation (Chung dkk., 2017), dan ease of movement (Huang dkk., 2017).

Kontribusi penelitian ini adalah dengan menemukan masa kerja sebagai moderator pada hubungan antara kepuasan kerja dan intensi meninggalkan organisasi. Kerangka teori yang digunakan dalam menjelaskan peran moderator masa kerja adalah side-bet theory (Becker, 1960) yang menjelaskan keengganan karyawan untuk meninggalkan organisasi ketika mereka merasa telah bekerja cukup lama di organisasi dan telah menginvestasikan waktu dan tenaga untuk organisasi.

\section{Intensi meninggalkan organisasi}

Turnover, atau proses keluarnya seseorang dari organisasi tempatnya bekerja merupakan sebuah fenomena yang tak jarang ditemui di berbagai organisasi, tak terkecuali pada institusi pendidikan. Mobley dkk. (1978) berpendapat bahwa terdapat tahapan-tahapan yang 
menggambarkan proses munculnya intensi untuk meninggalkan pekerjaan pada individu sebelum ke tahap turnover behavior. Mobley melihat bahwa tahapan ini dimulai pada kepuasan kerja yang dimiliki oleh individu. Pada tahap awal, individu akan menilai pekerjaan yang dimilikinya, dan kepuasan kerja ini juga dipengaruhi oleh usia dan masa kerja yang dimiliki oleh individu tersebut. Apabila individu memiliki ketidakpuasan pada pekerjaannya, maka tahap selanjutnya adalah munculnya pikiran untuk meninggalkan pekerjaannya, yang mana hal tersebut merupakan proses kognitif yang terjadi di individu (Mobley dkk., 1978). Pada tahap ini, individu akan mengevaluasi biaya yang diderita apabila ia memutuskan untuk keluar, dan apakah tindakannya akan menghasilkan sesuatu yang diharapkan (Mobley, 1977).

Apabila individu menganggap bahwa tindakannya untuk meninggalkan pekerjaannya dapat mendapatkan hasil yang diharapkan, maka tahap selanjutnya adalah munculnya intensi untuk mencari pekerjaan lain. Intensi ini dipengaruhi oleh kemungkinan bagi individu untuk mencari pekerjaan alternatif, yang mana hal ini juga dipengaruhi oleh umur dan/atau masa kerja individu, dan kepuasan kerja yang dimilikinya. Setelah individu berhasil mengevaluasi kemungkinan pekerjaanpekerjaan alternatif yang mungkin untuk didapatkan, maka individu tersebut cenderung akan memiliki intensi untuk tetap pada pekerjaannya, atau meninggalkan pekerjaannya. Hal ini juga dipengaruhi oleh kepuasan kerja yang dimilikinya, serta kemungkinan pekerjaanpekerjaan alternatif yang mungkin untuk didapatkan. Setelah melewati tahapan kognitif tersebut, apabila individu memutuskan untuk meninggalkan pekerjaannya, maka tahap terakhir yang muncul adalah turnover behavior dan withdrawal behavior. Tahapan ini merupakan hasil dari intensi yang sebelumnya sudah ada, sehingga menghasilkan sebuah perilaku (Mobley dkk., 1978). Perilaku pada tahap ini adalah ketika individu memutuskan untuk meninggalkan pekerjaannya dan memilih pekerjaan lain. Sebuah penelitian di Amerika menemukan sebanyak $30 \%$ guruguru baru meninggalkan profesinya dalam kurun waktu 5 tahun, dan sekitar 50\% tingkat turnover lebih banyak terjadi sekolah-sekolah yang tergolong miskin (Ronfeldt dkk., 2013). Fleener (2001, dalam Reynolds \& Wang, 2005) dalam studinya di Amerika, juga menemukan bahwa antara $25 \%$ - $50 \%$ guru baru mengundurkan diri dalam kurun waktu tiga tahun pertama masa mengajarnya. Fenomena tingginya tingkat turnover ini, juga ditemukan di beberapa sekolah di Indonesia, khususnya Jakarta dan sekitarnya. Beberapa penelitian terdahulu pada beberapa sekolah di wilayah Jakarta dan sekitarnya menemukan tingkat turnover yang cukup tinggi, yaitu antara 13\%, sampai dengan 25\% (Cipta, 2017; Suharno dkk., 2017). Tingkat turnover tersebut di atas termasuk dalam kategori tinggi jika dibandingkan dengan tingkat turnover di Indonesia pada seluruh industri yang mencapai $8 \%$ di tahun 2017 , 8\% di tahun 2018, 7\% di tahun 2019 menurut survey oleh Mercer Indonesia (Evandio, 2020; Movanita, 2018; Rahma, 2019).

Sekolah yang memiliki tingkat turnover rendah cenderung dapat merekrut guru yang memiliki pengalaman lebih jika dibandingkan dengan sekolah yang 
memiliki tingkat turnover yang tinggi (Loeb dkk., 2005). Beberapa kerugian bagi organisasi, termasuk sekolah, apabila memiliki tingkat turnover rate yang tinggi dapat digolongkan menjadi pecuniary cost (yaitu biaya yang dikeluarkan untuk merekrut maupun memberikan pelatihan/training kepada karyawan baru) dan nonpecuniary cost (biaya tidak tampak yang disebabkan oleh penurunan semangat kerja/low employee morale), dan menurunkan performa organisasi (Lee, 2018). Sejalan dengan pernyataan tersebut, Bryant dan Allen (2013) menambahkan bahwa kehilangan seorang karyawan dapat mengakibatkan munculnya gangguan dalam pekerjaan, berkurangnya produktivitas atau hubungan yang telah dibangun dengan customer bila bekerja di bidang jasa, hilangnya seorang mentor, mengurangi keberagaman, dan dapat mempengaruhi karyawan yang berharga lainnya untuk meninggalkan perusahaan tersebut.

Selain itu, penelitian-penelitian juga menemukan dampak-dampak lainnya pada sekolah yang memiliki tingkat turnover yang tinggi, antara lain menurunnya prestasi akademik siswa dan terganggunya perkembangan kognitif siswa (Kim dkk., 2020). Hal ini terjadi karena siswa yang merasa dekat atau terikat dengan guru tersebut akan merasa kehilangan, sehingga hal tersebut dapat mengganggu proses perkembangan kognitifnya dan dapat memperburuk prestasi akademik siswa tersebut. Selain menurunkan prestasi akademik dan mengganggu perkembangan kognitif siswa, tingginya tingkat turnover pada guru-guru yang berpengalaman ini juga dapat memperburuk kualitas program sekolah yang dijalankan. Hal ini karena kurangnya guru-guru yang mengerti kurikulum di sekolah tersebut secara komprehensif dan koheren (Kim dkk., 2020).

Mobley dkk. (1978) menyatakan bahwa terdapat beberapa tahapan kognitif sebelum individu memutuskan untuk keluar dari pekerjaannya, salah satunya adalah intensi meninggalkan organisasi (turnover intention). Secara umum, intensi meninggalkan organisasi adalah niat atau intensi yang dimiliki seseorang untuk meninggalkan pekerjaannya. Netemeyer dkk. (2004) menyatakan bahwa intensi untuk meninggalkan pekerjaan adalah pikiran dan/atau niat seseorang untuk berhenti dari pekerjaan yang dimilikinya.

Penelitian ini akan berfokus pada variabel intensi meninggalkan organisasi (turnover intentions), karena pada tahapan ini, guru masih berpikir untuk keluar tetapi belum benar-benar keluar dari organisasi. Organisasi masih dapat melakukan identifikasi pada penyebab intensi yang tinggi sehingga dapat melakukan intervensi untuk menurunkan intensi keluar dari organisasi (Purba dkk., 2016). Selain itu, sikap kerja negatif yang berhubungan dengan intensi keluar dari organisasi, seperti tingkat absensi yang tinggi, perilaku mengganggu di organisasi, dan sinisme pada organisasi, dapat menular kepada anggota organisasi lainnya sehingga menurunkan morale karyawan lainnya (Griffeth dkk., 2000).

\section{Kepuasan kerja dan intensi meninggalkan organisasi}

Di antara faktor penyebab intensi meninggalkan organisasi yang ditemukan dalam penelitian-penelitian sebelumnya, kepuasan kerja merupakan faktor yang paling konsisten berhubungan negatif dengan intensi meninggalkan organisasi (misalnya, Bravo dkk., 2019, De Simone 
dkk., 2018). Perasaan ketidakpuasan yang dialami oleh karyawan pada aspek-aspek pekerjaan akan menimbulkan perasaan tidak nyaman dan tidak adil yang meningkatkan keinginan untuk keluar dari organisasi. Spector (1997) menjelaskan bahwa kepuasan kerja dapat dilihat dalam dua pendekatan, yaitu global approach dan facets approach. Pada pendekatan global approach, kepuasan kerja dijelaskan sebagai sikap keseluruhan yang membuat seseorang itu menyukai atau tidak menyukai pekerjaannya, sedangkan pada pendekatan facets approach melihat setiap aspek dari pekerjaan untuk menentukan karyawan itu puas atau tidak puas. Menurut Spector (1997), aspekaspek kepuasan kerja terdiri atas gaji, promosi, atasan, tunjangan, imbalan secara non-finansial, prosedur operasi, rekan kerja, kondisi pekerjaan, dan komunikasi. Kepuasan karyawan pada aspek-aspek pekerjaannya akan menurunkan tingkat intensi untuk meninggalkan organisasi, karena takut kehilangan hal-hal yang telah diperoleh dari organisasi tersebut. Berdasarkan penjelasan tersebut, maka hipotesis penelitian ini adalah:

Hipotesis 1: Kepuasan kerja memiliki hubungan signifikan dan negatif dengan intensi meninggalkan organisasi

\section{Masa kerja sebagai moderator}

Secara logika, individu yang merasa tidak puas pada aspek-aspek pekerjaannya cenderung memiliki intensi yang tinggi untuk keluar dari organisasi. Namun demikian, ada situasi dimana karyawan yang tidak puas pada pekerjaannya tidak memiliki intensi untuk keluar dari organisasi. Hal ini mengindikasikan adanya variabel moderator yang memengaruhi hubungan antara kepuasan kerja dan intensi meninggalkan organisasi. Hal ini ditunjukkan dengan cukup banyaknya penelitian-penelitian yang menemukan variabel moderator di antara kepuasan kerja dan intensi meninggalkan organisasi. Chung dkk. (2017) misalnya pada penelitiannya yang dilakukan di dua bandara di Korea pada 492 petugas keamanan, menemukan bahwa Selfdetermined work motivation memoderasi hubungan antara kepuasan kerja dan intensi meninggalkan organisasi. Selain itu, sebuah penelitian di Cina pada pekerja pabrik juga menunjukkan bahwa kemudahan individu untuk berpindah (ease of movement), baik pekerjaan baru maupun tempat tinggal, juga dapat memengaruhi hubungan antara kepuasan kerja dan intensi meninggalkan pekerjaan (Huang dkk., 2017). Hal ini membuktikan bahwa walaupun seseorang memiliki kepuasan kerja yang rendah, ia cenderung memiliki intensi yang rendah untuk keluar dari organisasi karena pertimbangan lain.

Dalam penelitian ini, masa kerja akan diteliti sebagai moderator pada hubungan antara kepuasan kerja dan intensi meninggalkan organisasi. Masa kerja yang dimaksud mengacu kepada jumlah tahun yang dihabiskan seseorang pada sebuah pekerjaan di satu organisasi (Maden, 2014). Masa kerja sendiri memiliki peran yang penting sebagai prediktor bagi intensi meninggalkan organisasi dan tingkat turnover.

Penelitian-penelitian terdahulu menunjukkan bahwa terdapat hubungan signifikan negatif antara masa kerja dan intensi meninggalkan organisasi (Cotton \& Tuttle, 1986; Van Breukelen dkk., 2004). Fenomena ini dapat dijelaskan dengan teori side-bet yang dikemukakan oleh Becker (1960). Menurut Becker (1960), 
seorang pekerja akan merasa sulit untuk meninggalkan organisasi tempatnya bekerja apabila ia merasa bahwa ia telah menghabiskan "biaya" (tenaga, ide, investasi lainnya) selama suatu periode tertentu di organisasi tersebut. Hal ini juga didukung oleh penelitian yang dilakukan Emiroğlu dkk. (2015), yang dilakukan pada 297 karyawan sebuah hotel berbintang lima di Turki. Penelitian mereka menunjukkan bahwa karyawan yang telah bekerja lebih dari lima tahun cenderung memiliki intensi meninggalkan organisasi yang lebih rendah jika dibandingkan dengan karyawan yang memiliki masa kerja antara di bawah empat tahun. Dengan kata lain, semakin lama karyawan bekerja di sebuah organisasi, maka keinginan karyawan tersebut untuk meninggalkan organisasi akan semakin rendah.

Selain Emiroğlu dkk. (2015), Jung dkk. (2012) yang melakukan penelitian pada 316 responden pekerja hotel di 12 hotel berbintang lima di Seoul, Korea Selatan, menunjukkan bahwa meskipun burnout berpengaruh positif pada intensi meninggalkan organisasi, karyawan hotel yang mengalami burnout cenderung lebih sering berpikir untuk meninggalkan pekerjaannya jika memiliki masa kerja yang masih singkat dibandingkan jika memiliki masa kerja yang lebih lama (Jung dkk., 2012).

Dengan demikian, berdasarkan sidebet theory (Becker, 1960), meskipun karyawan memiliki tingkat kepuasan yang rendah pada berbagai aspek pekerjaannya, ia dapat saja memilih untuk tetap pada pekerjaannya jika ia merasa tidak ingin mengorbankan waktu yang telah dihabiskan untuk bekerja di organisasi tersebut. Berdasarkan penjelasan tersebut, hipotesis kedua dari penelitian ini adalah:

Hipotesis 2: Masa kerja memoderasi hubungan antara kepuasan kerja dengan intensi meninggalkan organisasi, dimana hubungan antara kepuasan kerja dan intensi meninggalkan organisasi lebih negatif dan signifikan pada karyawan yang memiliki masa kerja yang rendah dibandingkan dengan karyawan yang memiliki masa kerja yang tinggi.

\section{Metode}

\section{Partisipan dan desain penelitian}

Desain penelitian ini adalah non eksperimental dengan metode korelasional, yang bertujuan untuk melihat hubungan antara variabel. Berdasarkan fenomena tingginya tingkat turnover di sekolah di Jakarta dan sekitarnya, maka subyek penelitian ini adalah guru-guru sekolah swasta yang ada di wilayah Jakarta dan sekitarnya, karena guru merupakan salah satu core business unit di sebuah sekolah. Selain itu, guru di sekolah swasta juga relatif tidak terikat di sekolahnya dibandingkan guru sekolah negeri yang pada umumnya pegawai negeri sipil, sehingga guru sekolah swasta dapat lebih mudah berpindah ke sekolah lainnya.

Untuk mendapatkan responden, peneliti menghubungi Manajer SDM dari beberapa sekolah swasta yang ada di Jakarta dan sekitarnya melalui surat elektronik, untuk menginformasikan mengenai ruang lingkup penelitian ini dan meminta izin melakukan penelitian. Selanjutnya, koordinasi pengumpulan data di tiap sekolah dibantu oleh pihak SDM, dan pihak SDM akan mengirimkan 
kuesioner tersebut kepada tiap guru untuk diisi secara daring.

Karena keterbatasan akses pada data guru-guru swasta di Jakarta dan sekitarnya, teknik pengambilan sampel yang digunakan adalah convenience sampling, yang berarti bahwa pengambilan data dilakukan hanya pada guru yang mendapatkan informasi tentang penelitian ini dan bersedia berpartisipasi pada saat survei dilakukan. Sejatinya, dalam menentukan jumlah sampel penelitian, dapat dikatakan bahwa semakin banyak jumlah sampel, maka semakin besar juga kemungkinan bahwa sampel tersebut dapat mencerminkan populasi. Akan tetapi, menurut Crocker dan Algina (1986), jumlah sampel minimal yang diperlukan agar mendapatkan hasil yang baik adalah sejumlah 200 responden. Setelah kuesioner disebarkan, dengan keterbatasan dalam menghubungi responden, terkumpul 239 responden yang menjawab kuesioner dengan baik secara daring.

\section{Prosedur dan pengukuran}

Pada penelitian ini, kepuasan kerja akan diukur menggunakan alat ukur Job Satisfaction Survey (JSS) yang dikembangkan oleh Spector (1997), dan telah diadaptasi ke dalam Bahasa indonesia oleh Desriyanto (2015), dengan nilai reliabilitas $\alpha$ sebesar $=.96$. Jumlah aitem pada alat ukur ini adalah 36 aitem dan terdiri atas 9 aspek (gaji, promosi, atasan, tunjangan, imbalan secara nonfinansial, prosedur operasi, rekan kerja, kondisi pekerjaan, dan komunikasi) dan berskala Likert 1-6 (1 = sangat tidak setuju, 2 = tidak setuju, 3 = agak tidak setuju, 4 = agak setuju, $5=$ setuju, $6=$ sangat setuju). Job Satisfaction Survey ini dapat mengukur kepuasan kerja secara global (Zeytinoglu dkk., 2013) maupun pada tiap facet (Desriyanto, 2015). Pada penelitian ini, peneliti akan melihat kepuasan kerja berdasarkan global approach, yakni melihat kepuasan kerja secara keseluruhan, karena tujuan dari penelitian ini adalah untuk melihat skor rata-rata kepuasan kerja guru yang didapatkan dari rata-rata skor setiap faset kepuasan kerja. Penelitian ini menggunakan alat ukur intensi meninggalkan organisasi yang dikembangkan oleh (Mobley dkk., 1978), yang telah diadaptasi ke dalam Bahasa Indonesia oleh Indirasari dkk. (2019) dengan nilai reliabilitas $\alpha=.86$. Alat ukur ini terdiri dari tiga aitem dengan skala likert 1-5 ( 1 = sangat tidak setuju, $2=$ tidak setuju, 3 = ragu-ragu, $4=$ setuju, $5=$ sangat setuju). Masa kerja diukur dalam tahun lama mengajar di sekolah sekarang, yang dikategorikan menjadi empat kelompok ( $1=1-2$ tahun, $2=2-4$ tahun, 3 = 4-5 tahun, $4=>5$ tahun).

Untuk menganalisis data yang telah didapatkan, peneliti akan menggunakan aplikasi SPSS versi 26. Teknik analisis yang digunakan untuk melihat hubungan antar variabel adalah Pearson's correlation dan untuk menghitung interaksi antara masa kerja pada hubungan antara kepuasan kerja dan intensi meninggalkan organisasi, peneliti akan menggunakan SPSS PROCESS Moderation Model 1 (Hayes, 2013). Metode ini dipilih karena menggunakan teknik bootstrapping. Selain itu, dibandingkan dengan metode lain seperti Structural Equation Modeling (SEM), kelebihan dari PROCESS macro dari Hayes adalah mudah digunakan, tetapi hasilnya sama dengan ketika 
menggunakan SEM yang lebih kompleks (Hayes, 2013).

\section{Hasil}

Karakteristik dari sampel terlihat pada Tabel 1. Adapun rata-rata dari usia responden adalah 33.93 tahun $(S D=8.26)$. Mayoritas responden berjenis kelamin wanita, yakni 196 orang (82\%), sedangkan laki-laki sejumlah 43 orang (18\%). Ratarata dari responden telah bekerja di sekolah saat ini adalah 2.71 tahun $(S D=$ 1.20). Sejumlah 192 responden (80\%) memiliki pendidikan terakhir Sarjana, 40 (17\%) memiliki pendidikan terakhir S2, dan 7 responden (3\%) memiliki pendidikan di bawah sarjana.

Tabel 2 menunjukkan hasil analisis korelasi antar variabel, nilai rata-rata, dan nilai standar deviasi. Berdasarkan hasil analisis korelasi pada Tabel 2, terdapat hubungan signifikan dan negatif antara kepuasan kerja dan intensi meninggalkan organisasi $(r=-.66, p<.001)$. Tabel 2 juga menunjukkan bahwa terdapat hubungan signifikan dan negatif antara masa kerja dengan intensi meninggalkan organisasi $(r=-.25, p<.001)$. Hal ini menunjukkan bahwa semakin lama seorang guru bekerja, maka intensi meninggalkan organisasi yang dimilikinya akan semakin rendah. Sementara itu, tidak terdapat hubungan yang signifikan antara kepuasan kerja dan masa kerja. Berdasarkan hasil uji korelasi antara variabel-variabel penelitian, dapat disimpulkan bahwa pengujian regresi moderasi dapat dilanjutkan, karena tidak ada korelasi yang signifikan antara kepuasan kerja dan masa kerja.

Tabel 1. Analisa Deskriptif dari Responden.

\begin{tabular}{|c|c|c|c|c|}
\hline & $M$ & $S D$ & $\%$ & Jumlah \\
\hline Usia & 33.93 & 8.26 & 100 & 239 \\
\hline Jenis Kelamin & & .39 & & 239 \\
\hline Perempuan & & & 82 & 196 \\
\hline Laki-laki & & & 18 & 43 \\
\hline Pendidikan & & & & 239 \\
\hline SMA & & & 1 & 3 \\
\hline Diploma 3 & & & 2 & 4 \\
\hline Strata 1 & & & 80 & 192 \\
\hline Strata 2 & & & 17 & 40 \\
\hline Masa Kerja & & 1.2 & & \\
\hline 1-2 tahun & & & 22 & 53 \\
\hline 2-4 tahun & & & 25 & 59 \\
\hline 4-5 tahun & & & 13 & 32 \\
\hline$>5$ tahun & & & 40 & 95 \\
\hline
\end{tabular}


Tabel 2. Hasil Analisis Korelasi antara Kepuasan Kerja, Masa Kerja, dan Intensi Meninggalkan Organisasi.

\begin{tabular}{lccccc}
\hline \multicolumn{1}{c}{ Variabel } & $M$ & $S D$ & $1)$ & $2)$ & 3 \\
\hline 1) Kepuasan Kerja & 3.98 & .67 & - & - & \\
2) Masa Kerja & 2.71 & 1.20 & .09 & $-.25^{* *}$ & - \\
$\begin{array}{l}\text { 3) Intensi } \\
\text { Meninggalkan } \\
\text { Organisasi }\end{array}$ & 2.39 & 1.13 & $-.66^{* *}$ & & \\
\hline
\end{tabular}

Catatan. $N=239 . * * p<.001$. Masa kerja diukur dalam kategori.

Tabel 3 menunjukkan hasil uji moderasi masa kerja pada hubungan antara kepuasan kerja dan intensi meninggalkan organisasi. Berdasarkan hasil analisis pada Tabel 3, kepuasan kerja memprediksi intensi meninggalkan organisasi secara negatif dan signifikan $(b=-1.07$, $S E=.08,95 \% C I[-1.227,-.910])$. Berdasarkan hasil ini, maka dapat disimpulkan bahwa Hipotesis 1 didukung oleh data.

Tabel 3. Regresi Uji Moderasi Masa Kerja pada Hubungan Kepuasan Kerja dengan Intensi Meninggalkan Organisasi.

\begin{tabular}{lccc}
\hline Variabel Penelitian & \multicolumn{3}{c}{$\begin{array}{c}\text { Intensi Meninggalkan Organisasi } \\
95 \% \mathrm{CI}\end{array}$} \\
\hline Konstanta & $2.38^{* *}$ & .05 & {$[2.273,2.484]$} \\
Kepuasan Kerja & $-1.07 * *$ & .08 & {$[-1.227,-.910]$} \\
Masa Kerja & $-.18^{* *}$ & .04 & {$[-.267,-.092]$} \\
Kepuasan Kerja x & $.14 *$ & .07 & {$[.003, .270]$} \\
Masa Kerja & .48 & & \\
$R^{2}$ & 71.59 \\
$F$
\end{tabular}


Gambar 1. Simple slope Interaksi antara Masa Kerja dan Kepuasan Kerja terhadap Intensi Meninggalkan Organisasi

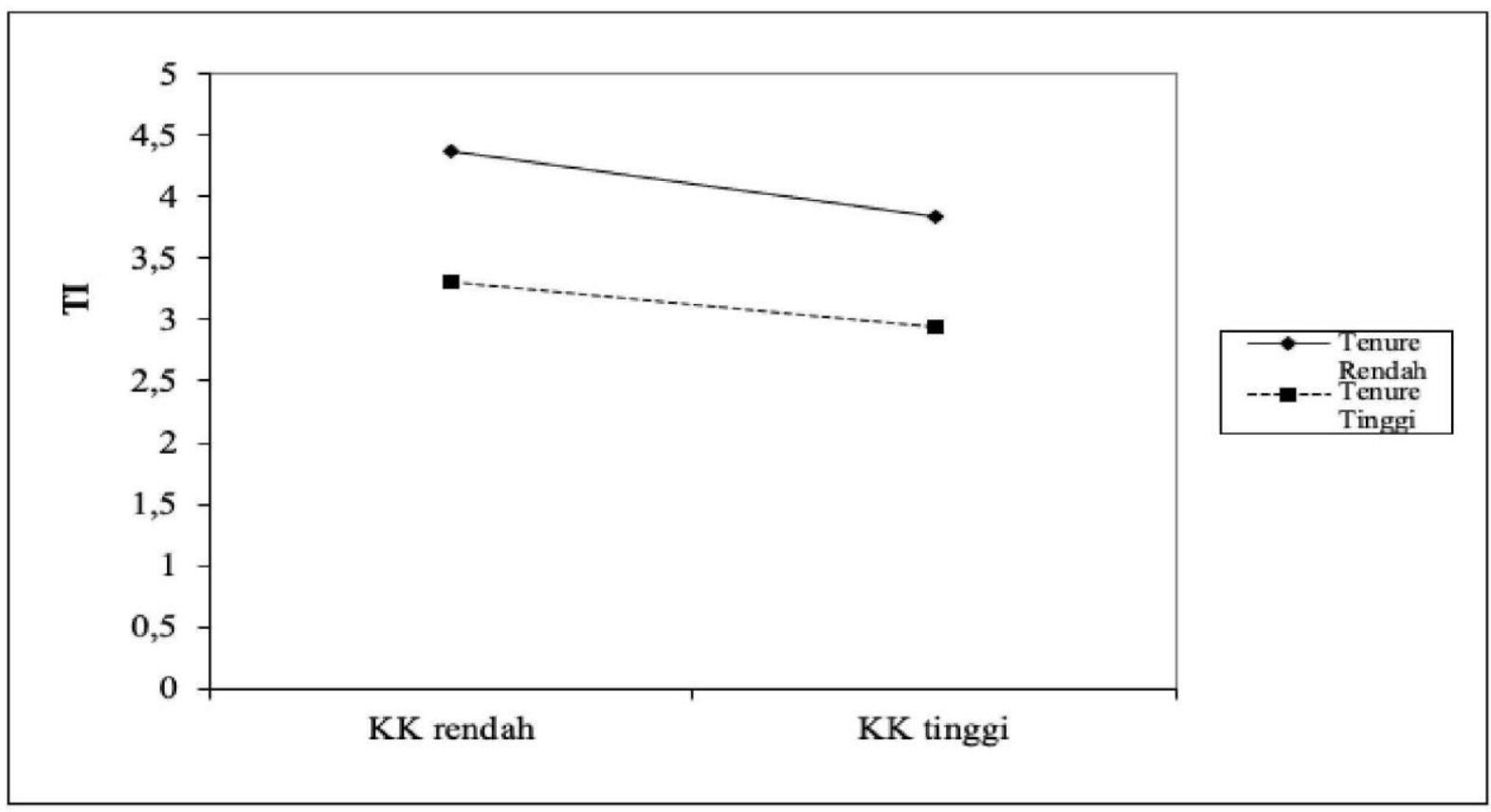

Keterangan $. \mathrm{KK}=$ kepuasan kerja. Tenure $=$ masa kerja. $\mathrm{TI}=$ Intensi meninggalkan organisasi

\section{Diskusi}

Penelitian ini bertujuan untuk melihat hubungan antara kepuasan kerja dan intensi meninggalkan organisasi, dan melihat peran moderasi masa kerja pada hubungan antara kepuasan kerja dan intensi meninggalkan organisasi. Hasil penelitian menunjukkan bahwa kepuasan kerja memprediksi intensi meninggalkan organisasi secara negatif dan signifikan. Hasil ini sejalan dengan penelitianpenelitian sebelumnya yang menemukan bahwa kepuasan kerja memprediksi intensi meninggalkan organisasi secara negatif dan signifikan (Bonenberger dkk., 2014; Bravo dkk., 2019; Chung dkk., 2017; De Simone dkk., 2018; Huang dkk., 2017; Kafumbu, 2019; Mahdi dkk., 2016; Zeffane \& Melhem, 2017). Penelitianpenelitian di atas dilakukan pada berbagai populasi yang berbeda, seperti buruh pabrik (Huang dkk., 2017), petugas medis MEDIAPSI | 2021, Vol. 7, No. 2, 150-165
(Bonenberger dkk., 2014), dan pegawai kantor (Mahdi dkk., 2016), sehingga dapat ditarik kesimpulan bahwa hubungan kepuasan kerja dan intensi meninggalkan organisasi berlaku lintas sampel/populasi.

Effect size dari korelasi antara kepuasan kerja dan intensi meninggalkan organisasi yang ditemukan dalam penelitian ini tergolong besar, dan hasil ini sama dengan beberapa penelitian sebelumnya (Bravo dkk., 2019; Chung dkk., 2017). Penelitian ini juga menemukan masa kerja berperan sebagai moderator pada hubungan antara kepuasan kerja dan intensi meninggalkan organisasi. Hasil ini menunjukkan bahwa terdapat boundary conditions dalam hubungan antara kepuasan kerja dan intensi meninggalkan organisasi, seperti yang telah ditemukan oleh penelitian-penelitian sebelumnya (misalnya, Chung dkk., 2017; Huang dkk., 2017). Hasil penelitian ini 
menunjukkan peran moderator masa kerja pada hubungan antara kepuasan kerja dan intensi meninggalkan organisasi cenderung lemah, sehingga hubungan antara kepuasan kerja dan intensi meninggalkan organisasi masih signifikan, baik pada keadaan masa kerja tinggi maupun masa kerja rendah. Hal ini kemungkinan disebabkan masa kerja tidak menggunakan data masa kerja dalam tahun yang sebenarnya, melainkan menggunakan kategorisasi sehingga kekuatan analisis moderasinya menjadi lebih lemah karena kategorisasi kurang dapat membedakan masa kerja yang tinggi maupun rendah. Hasil ini sejalan dengan side-bet theory yang dikemukakan oleh Becker (1960), yang juga menunjukkan bahwa walaupun seorang guru memiliki tingkat kepuasan kerja yang rendah namun memiliki masa kerja yang lama, maka intensi untuk meninggalkan organisasi yang dimilikinya akan cenderung lebih rendah, begitu juga sebaliknya.

Terdapat beberapa implikasi teoretis dari penelitian ini. Pertama, teori side-bets yang digunakan efektif untuk menjelaskan peran moderasi dari masa kerja. Selain masa kerja, masih banyak variabel yang mewakili side-bets yang dapat dipertimbangkan sebagai moderator pada hubungan antara kepuasan kerja dan intensi meninggalkan organisasi. Salah satunya adalah alternatif pekerjaan lain (perceived job alternatives). Karena penelitian ini dilakukan di daerah urban, ada banyak sekolah swasta di Jakarta dan sekitarnya yang dapat menjadi pilihan tempat kerja bagi guru yang memutuskan untuk keluar dari sekolahnya saat ini. Oleh karena itu, penelitian lanjutan diperlukan dengan melihat peran persepsi individu pada pada alternatif pekerjaan lain pada hubungan antara kepuasan kerja dan intensi meninggalkan sekolah.

Kedua, penelitian ini mendukung penelitian sebelumnya tentang peran job embeddedness pada variabel turnover (Crossley dkk., 2007; Mitchell dkk., 2001; Purba et al., 2016). Keterikatan pada pekerjaan ini merupakan salah satu hal yang perlu diperhatikan dalam memprediksi turnover pada karyawan, karena menurut Mitchell dkk. (2001), sikap kerja (work attitude) hanya memiliki peran yang kecil pada retensi dan keluarnya karyawan dari organisasi. Keterikatan ini didasari oleh tiga aspek, yakni links (hubungan secara formal maupun informal terhadap seseorang dan organisasi), fit (kenyamanan karyawan pada lingkungan kerja dan non-kerja), dan sacrifice (hal-hal yang harus dikorbankan apabila seseorang meninggalkan pekerjaannya) (Mitchell dkk., 2001). Karena berbagai penelitian terkini mendukung job embeddedness sebagai prediktor terbaik turnover (Afsar dkk., 2018; Purba dkk., 2016; Sender dkk., 2018), maka penelitian selanjutnya disarankan untuk mempertimbangkan memasukkan job embeddedness sebagai moderator pada hubungan antara kepuasan kerja dan intensi meninggalkan organisasi.

Dari hasil penelitian ini, terdapat implikasi praktis yang dapat dijadikan dasar oleh organisasi dalam merancang program retensi bagi guru, seperti program pelatihan dan pengembangan keterampilan dalam mengajar. Program ini bertujuan untuk meningkatkan kepuasan guru pada aspek pengembangan diri. Program lain adalah pengembangan karir untuk guru sesuai dengan performa yang dimilikinya dan arah karir yang diinginkan, seperti pelatih guru, kepala sekolah, peneliti, dan 
lainnya. Selain itu, sekolah dapat menerapkan program selebrasi untuk merayakan setiap milestone yang telah ditempuh oleh guru, misalnya dengan memberikan bonus makan siang gratis, gratis liburan, atau voucher belanja. Program ini lebih dari sekadar pengakuan dan pujian atas pencapaian guru, karena guru merasa diperhatikan oleh sekolah dan merasa puas dan bangga akan pekerjaannya. Dengan adanya program retensi ini, diharapkan dapat meningkatkan masa kerja guru, sehingga apabila masa kerja yang dimilikinya meningkat, maka ia akan cenderung bertahan pada pekerjaannya meskipun tidak puas pada aspek-aspek lain dalam pekerjaannya.

Peneliti menyadari bahwa terdapat beberapa keterbatasan pada penelitian ini. Pertama, penelitian ini bersifat cross sectional, sehingga tidak dapat menjelaskan hubungan kausal antar variabel penelitian. Untuk itu, penelitian selanjutnya disarankan untuk menggunakan metode longitudinal atau eksperimen. Kedua, semua data diambil secara self-report, yang memiliki resiko common method bias dalam hasil penelitian (Podsakoff dkk., 2003). Penelitian selanjutnya dapat mengambil data secara temporal separation, dengan memisahkan pengambilan data prediktor dan outcome setidaknya dua minggu (Podsakoff dkk., 2003).

\section{Kesimpulan}

Hasil penelitian ini mengkonfirmasi teori side-bets, dimana guru yang merasa puas pada aspek-aspek pekerjaannya akan memiliki intensi yang rendah untuk keluar dari sekolahnya. Namun demikian, guru yang lebih lama bekerja di sekolah akan memiliki intensi yang lebih rendah untuk keluar dari sekolahnya meskipun ia tidak puas pada aspek-aspek pekerjaannya dibandingkan guru yang belum lama bekerja di sekolah. Penelitian selanjutnya dapat meneliti variabel-variabel yang tergolong dalam side-bet (seperti job embeddedness, pendapatan, dan alternatif pekerjaan lain).

\section{Daftar Pustaka}

Afsar, B., Shahjehan, A., \& Shah, S. I. (2018). Frontline employees' highperformance work practices, trust in supervisor, job-embeddedness and turnover intentions in hospitality industry. International Journal of Contemporary

Hospitality

\section{Management.}

https://doi.org/10.1108/IJCHM-112016-0633

Becker, H. S. (1960). Notes on the concept of commitment. American journal of Sociology, $\quad$ 66(1), 32-40. https://doi.org/10.1086/222820

Bonenberger, M., Aikins, M., Akweongo, P., \& Wyss, K. (2014). The effects of health worker motivation and job satisfaction on turnover intention in Ghana: A cross-sectional study. Human Resources for Health, 12(1), 1-12. https://doi.org/10.1186/14784491-12-43

Bravo, G. A., Won, D., \& Chiu, W. (2019). Psychological contract, job satisfaction, commitment, and turnover intention: Exploring the moderating role of psychological contract breach in National Collegiate Athletic Association coaches. International Journal of Sports Science and Coaching, 14(3), 273-284.

https://doi.org/10.1177/1747954119 
848420

Bryant, P. C., \& Allen, D. G. (2013). Compensation, Benefits and Employee Turnover. Compensation \& Benefits Review, 45(3), 171-175. https://doi.org/10.1177/0886368713 494342

Chao, M. C., Jou, R. C., Liao, C. C., \& Kuo, C. W. (2015). Workplace stress, job satisfaction, job performance, and turnover intention of health care workers in rural Taiwan. Asia-Pacific Journal of Public Health, 27(2), NP1827NP1836. https://doi.org/10.1177/1010539513 506604

Chung, E. K., Jung, Y., \& Sohn, Y. W. (2017). A moderated mediation model of job stress, job satisfaction, and turnover intention for airport security screeners. Safety Science, 98 , 89-97. https://doi.org/10.1016/j.ssci.2017.0 6.005

Cipta, H. (2017). Pengaruh Kepercayaan terhadap Turnover Guru SD Swasta di Kecamatan Jatiasih Kota Bekasi. Holistika: Jurnal Ilmiah PGSD, 1(2), $\quad$ 81-86. https://jurnal.umj.ac.id/index.php/hol istika/article/view/2500/2068

Cotton, J. L., \& Tuttle, J. M. (1986). Employee turnover: A meta-analysis and review with implications for research. Academy of Management, 11(1), $\quad 55-70$. https://doi.org/10.5465/amr.1986.42 82625

Crocker, L., \& Algina, J. (1986). Introduction to classical and modern test theory. Rinehart and Winston.

Crossley, C. D., Bennett, R. J., Jex, S. M.,
\& Burnfield, J. L. (2007). Development of a global measure of job embeddedness and integration into a traditional model of voluntary turnover. Journal of Applied Psychology, 92(4), 1031-1042. https://doi.org/10.1037/0021-

9010.92.4.1031

De Simone, S., Planta, A., \& Cicotto, G. (2018). The role of job satisfaction, work engagement, self-efficacy and agentic capacities on nurses' turnover intention and patient satisfaction. Applied Nursing Research, 39, 130-140. https://doi.org/10.1016/j.apnr.2017.1 1.004

Desriyanto, N. (2015). Hubungan antara job satisfaction dan turnover intention: Rancangan intervensi training effective communication pada supervisor di PT XYZ [Tesis, Universitas Indonesia]. https://library.ui.ac.id/detail?id=2041 4962\&lokasi=lokal

Emiroğlu, B. D., Akova, O., \& Tanrıverdi, H. (2015). The relationship between turnover intention and demographic factors in hotel businesses: A study at five star hotels in Istanbul. Procedia - Social and Behavioral Sciences, 207, 385-397. https://doi.org/10.1016/j.sbspro.2015 .10 .108

Evandio, A. (2020, Januari 2). Survei: Gaji karyawan naik, perekrutan menurun. Bisnis. https://finansial.bisnis.com/read/202 00102/55/1186270/survei-gajikaryawan-naik-perekrutan-menurunGriffeth, R. W., Hom, P. W., \& Gaertner, S. (2000). A meta-analysis of antecedents and correlates of 
employee turnover: Update, moderator tests, and research implications for the next millennium. Journal of Management, 26(3), 463488.

https://doi.org/10.1177/0149206300 02600305

Hayes, A. F. (2013). Introduction to mediation, moderation, and conditional process analysis: A regression-based approach. Guilford Press.

Huang, S., Chen, Z., Liu, H., \& Zhou, L. (2017). Job satisfaction and turnover intention in China: The moderating effects of job alternatives and policy support. Chinese Management Studies, 11(4), 689-706. https://doi.org/10.1108/CMS-122016-0263

Indirasari, D. T., Purba, D. E., \& Anindita, R. (2019). Future time perspective and turnover intention: The mediating role of resilience. Psikohumaniora: Jurnal Penelitian Psikologi,4(1), 1-12. https://doi.org/10.21580/pjpp.v4i1.3 120

Jung, H. S., Yoon, H. H., \& Kim, Y. J. (2012). Effects of culinary employees' role stress on burnout and turnover intention in hotel industry: moderating effects on employees' tenure. Service Industries Journal, 32(13), 21452165.

https://doi.org/10.1080/02642069.20 11.574277

Kafumbu, F. T. (2019). Job satisfaction and teacher turnover intentions in Malawi: A quantitative assessment. International Journal of Educational Reform, 28(2), 207-226. https://doi.org/10.1177/1056787919 841501

Kartika, G., \& Purba, D. E. (2018). Job satisfaction and turnover intention: The mediating effect of affective commitment. Psychological Research on Urban Society, 1(2), 100-106.

http://doi.org/10.7454/proust.v1i2.34

Kim, J., Shin, Y., Tsukayama, E., \& Park, D. (2020). Stress mindset predicts job turnover among preschool teachers. Journal of School Psychology, 78, 13-22. https://doi.org/10.1016/j.jsp.2019.11. 002

Lee, S. (2018). Employee turnover and organizational performance in U.S. federal agencies. American Review of Public Administration, 48(6), 522-534.

https://doi.org/10.1177/0275074017 715322

Lee, S., Fernandez, S., \& Chang, C. (2018). Job Scarcity and voluntary turnover in the U.S. federal bureaucracy. Public Personnel Management, 47(1), 3-25. https://doi.org/10.1177/0091026017 732798

Loeb, S., Darling-Hammond, L., \& Luczak, J. (2005). How teaching conditions predict teacher turnover in California schools. Peabody Journal of Education, 80(3), 44-70. https://doi.org/10.1207/s15327930pj e8003_4

Maden, C. (2014). Impact of fit, involvement, and tenure on job satisfaction and turnover intention. Service Industries Journal, 34(14), 1113-1133. https://doi.org/10.1080/02642069.20 
14.939644

Mahdi, A. F., Zin, M. Z. M., Nor, M. R. M., Sakat, A. A., \& Naim, A. S. A. (2012). The relationship between job satisfaction and turnover intention. American Journal of Applied Sciences, 9(9), 1518-1526. https://doi.org/10.3844/ajassp.2012.1 518.1526

Mitchell, T. R., Holtom, B. C., Lee, T. W., Sablynski, C. J., \& Erez, M. (2001). Why people stay: Using job embeddedness to predict voluntary turnover. Academy of Management Journal, 44, 1102-1121. https://doi.org/10.2307/3069391

Mobley, W. H. (1977). Intermediate linkages in the relationship between job satisfaction and employee turnover. Journal of Applied Psychology, 62(2), 237-240. https://doi.org/10.1037/00219010.62.2.237

Mobley, W. H., Horner, S. O., \& Hollingsworth, A. T. (1978). An evaluation of precursors of hospital employee turnover. Journal of Applied Psychology, 63(4), 408-414. https://doi.org/10.1037/00219010.63.4.408

Movanita, A. N. K. (2018, Desember 7). 1 dari 4 Pegawai "Resign" Punya Keahlian yang Dibutuhkan Perusahaan. Kompas. https://ekonomi.kompas.com/read/20 18/12/07/101938426/1-dari-4pegawai-resign-punya-keahlianyang-dibutuhkanperusahaan?page $=$ all

Netemeyer, R. G., Brashear-Alejandro, T., \& Boles, J. S. (2004). A crossnational model of job-related outcomes of work role and family role variables: A retail sales context.

Journal of the Academy of Marketing Science, 32(1), 49-60. https://doi.org/10.1177/0092070303 259128

Podsakoff, P. M., MacKenzie, S. B., Lee, J. Y., \& Podsakoff, N. P. (2003). Common method biases in behavioral research: A critical review of the literature and recommended remedies. Journal of Applied Psychology, 88(5), 879-903. https://doi.org/10.1037/00219010.88.5.879

Purba, D. E., Oostrom, J. K., Born, M. P., \& Van Der Molen, H. T. (2016). The relationships between trust in supervisor, turnover intentions, and voluntary turnover: Testing the mediating effect of on-the-job embeddedness. Journal of Personnel Psychology, 15(4), 174-183. https://doi.org/10.1027/18665888/a000165

Rahma, A. (2019, Desember 26). Tren perekrutan karyawan indonesia bakal melambat di 2020. Liputan6. https://www.liputan6.com/bisnis/rea d/4142274/tren-perekrutankaryawan-indonesia-bakalmelambat-di-2020

Reynolds, A., \& Wang, L. (2005). Teacher retention: What role does professional development school preparation play? New Educator, 1(3), 205-229. https://doi.org/10.1080/1547688059 0966312

Ronfeldt, M., Loeb, S., \& Wyckoff, J. (2013). How teacher turnover harms student achievement. American Educational Research Journal, 50(1), 4-36. 
https://doi.org/10.3102/0002831212 463813

Rubel, M. R. B., Kee, D. M. H., \& Rimi, N. N. (2017). The mediating role of work-family conflict on role stressors and employee turnover intention relationship in labouroriented organizations. Global Business Review, 18(6), 1384-1399. https://doi.org/10.1177/0972150917 713061

Sender, A., Rutishauser, L., \& Staffelbach, B. (2018). Embeddedness across contexts: A two-country study on the additive and buffering effects of job embeddedness on employee turnover. Human Resource Management Journal, 28(2), 340$356 . \quad$ https://doi.org/10.1111/17488583.12183

Spector, P. E. (1997). Job satisfaction: Application, assessment, causes, and consequences. SAGE Publications, Inc.

Suharno, P., Ketut, S., Setyadi, \& Farida, E. (2017). The effect of organizational commitment toward turnover. Russian Journal of Agricultural and Socio-Economic Sciences, 2, 55-66. https://doi.org/10.18551/rjoas.201702.07

Swider, B. W., Boswell, W. R., \& Zimmerman, R. D. (2011).
Examining the job search-turnover relationship: The role of embeddedness, job satisfaction, and available alternatives. Journal of Applied Psychology, 96(2), 432-441. https://doi.org/10.1037/a0021676

Van Breukelen, W., Van Der Vlist, R., \& Steensma, H. (2004). Voluntary employee turnover: Combining variables from the "traditional" turnover literature with the theory of planned behavior. Journal of Organizational Behavior, 25(7), 893-914.

https://doi.org/10.1002/job.281

Zeffane, R., \& Bani Melhem, S. J. (2017). Trust, job satisfaction, perceived organizational performance and turnover intention: A public-private sector comparison in the United Arab Emirates. Employee Relations, 39(7), 1148-1167. https://doi.org/10.1108/ER-06-20170135

Zeytinoglu, I. U., Yilmaz, G., Keser, A., Inelmen, K., Uygur, D., \& Özsoy, A. (2013). Job satisfaction, flexible employment and job security among Turkish service sector workers. Economic and Industrial Democracy, 34(1), 123-144. https://doi.org/10.1177/0143831X11 434845 